\title{
ANALISIS EDIBLE FILM DARI TEPUNG JAGUNG PUTIH (Zea mays L.) TERMODIFIKASI GLISEROL DAN KARAGENEN
}

\author{
Sahri Yanti
}

Fakultas Teknologi Pertanian Universitas Teknologi Sumbawa, Indonesia

Author email: sahri.yanti@uts.ac.id

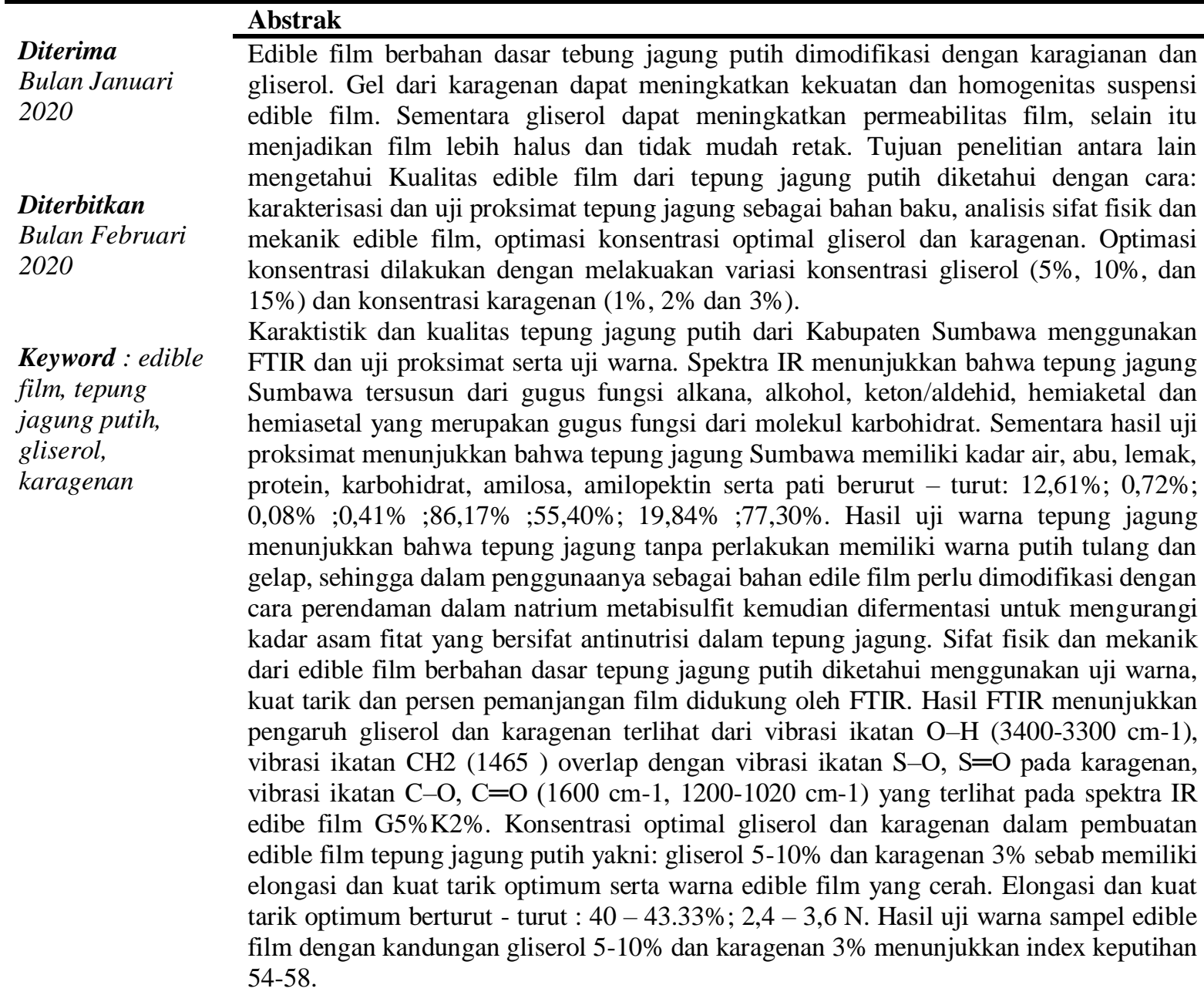

\section{PENDAHULUAN}

Plastik merupakan pengemas makanan yang banyak digunakan. Plastik terbuat dari polimer hasil ekstraksi minyak bumi dan plastik semacam ini memiliki sifat barrier terhadap oksigen, karbondioksida maupun dengan uap air (Ardiansyah, 2011). Konsumsi plastik di Indonesia diproyeksikan tumbuh sebanyak $6 \%$ pada tahun 2019 dari 5,5 juta ton tahun 2017 (Andri, 2017). Kemasan plastik memiliki kelemahan sebagai bahan pengemas yaitu dapat mencemari lingkungan karena sifatnya nonbiodegradable, selain itu plastik dapat mencemari makanan karena adanya zat yang berpotensi menyebabkan kangker (Huri, dan Fithri, 2014) Edible film merupakan lapisan tipis pengemas primer makanan dan penahan transfer berat seperti oksigen, cahaya, uap air dan lemak (Estiningtyas,
H.R, 2010). Penggunaan edible film dalam produk pangan dan teknologi pengolahannya masih terbatas, sehingga, perlu dikembangkan. Edible film dapat dibuat dari berbagai polisakarida, protein, lipid dan kombinasi ketiganya (Kusumawati, Dyah Hayu; Putri, Widya Dwi Rukmini; 2013). Tepung jagung putih merupakan solusi yang menarik sebagai pembungkus pangan yang inovatif karena mengandung polisakarida yang merupakan salah satu komponen penyusun edible film. Potensi jagung putih di Sumbawa telah dilaporkan tahun 2017 yakni sebanyak 68. 981 ton/tahun. Pengelohannya pun terbatas hanya direbus atau dibakar menjadi menu saat bersantai.

Proses pembuatan edible film dari hidrokoloid (protein, pati polisakarida) menghasilkan film yang rapuh, kaku, mudah sobek, 
sulit menyerap air dan kasar sehingga diperlukan bahan tambahan yang bersifat menyerap air dan dapat meningkatkan permeabiltas film. Bahan tersebut adalah karagenen dan gliserol. Plastisitas film dapat ditingkatkan oleh plasticizer atau bahan organik dengan berat molekul ringan, yang ditambahkan untuk memperlemah kekakuan film (Gennadios, 2002).

Bahan plasticizer yang digunakan dalam penelitian ini adalah gliserol agar mengurangi kerapuhan dan meningkatkan fleksibilitas serta ketahanan film. Menurut Gontard, Guilbert, \& Cuk (1993) gliserol dapat meningkatkan permeabilitas film terhadap uap air karena sifat gliserol yang hidrofilik. Gliserol mudah larut dalam air, meningkatkan kekentalan larutan, mengikat air dan menurunkan aktifitas kadar air (Linsay, 1985). Selain gliserol, karagenen juga ditambahkan agar dapat membentuk gel yang baik, elastis, dapat dimakan dan dapat diperbaharui (Handito, 2011). Penggunaan karagenan dalam jumlah yang banyak, menyebabkan kemampuan mengikat air yang lebih baik sehingga memberikan matrik gel yang dapat meningkatkan sifat mekanik dari pengemas. Menurut Carriedo, (1994), gel dari karagenan dapat digunakan dalam pelapisan makanan.

Kombinasi dari berbagai bahan berupa tepung jagung putih, karagenan dan gliseol dalam pembuatan edible film akan dikaji sifat fisik dan sifat mekaniknya. Karakterisasi tepung jagung serta optomasi konsentrasi karagenan dan gliserol pun akan dilakukan agar diperoleh edible yang berkualitas. Berdasarkan uraian diatas, peneliti tertarik untuk melakukan penelitian dengan judul Analisis Edible Film Dari Tepung Jagung Putih (Zea mays L.) Termodifikasi Gliserol Dan Karagenen. Adapun tujuan penelitian adalah: (a) Mengetahui karaktistik dan kualitas tepung jagung putih dari Kabupaten Sumbawa (b) Mengetahui sifat fisik dan mekanik dari edible film berbahan dasar tepung jagung putih. (c) Mengetahui konsentrasi optimal gliserol dan karagenan dalam pembuatan edible film tepung jagung putih.

\section{LANDASAN TEORI}

\section{Jagung}

Jagung dapat tumbuh dengan baik di daerah beriklim sedang yang panas seperti beriklim subtropis, namun dapat pula tumbuh dengan baik pada daerah tropis. Jagung dapat dimanfaatkan sebagai sumber karbohidrat, pakan ternak, dapat diambil minyaknya, serta dijadikan bahan baku berbagai macam industri. Jagung yang telah direkayasa genetikanya juga dapat digunakan untuk bahan farmasi (Azra, 2012). Komposisi jagung lengkap terdiri dari kelobot, tongkol jagung, biji jagung, dan rambut. Kelobot merupakan kelopak atau daun buah yang berguna sebagai pembungkus dan pelindung biji jagung. Komposisi biji jagung (Geochembio, 2010) dapat dilihat pada gambar 1.

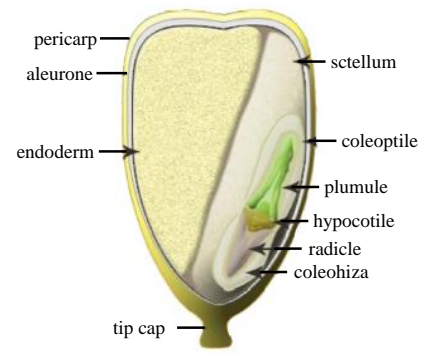

\section{Gambar 1. Komponen jagung}

Anatomi biji jagung terdiri dari kulit perikarp $(5,3 \%)$, endosperm $(82,9 \%)$, lembaga $(11,1 \%)$, dan tip cap $(0,8 \%)$ (Watson, 2003). Bagian terbesar dari biji jagung yaitu endosperm. Endosperm jagung terdiri dari dua bagian yaitu endosperm keras dan endosperm lunak. Lapisan keras memiliki 1,5\% sampai 2,0\% kandungan protein lebih besar dibandingkan lapisan lunak dan tidak rusak selama pengeringan. Bagian endosperm lunak mengandung pati. Jagung yang normal mengandung 11,5\% lembaga dari berat biji jagung. Bagian terkecil pada biji jagung adalah tip cap atau tudung pangkal. Tudung pangkal biji dapat bertahan atau terlepas dari biji selama proses pemipilan jagung.

Komponen utama yang terdapat dalam jagung adalah karbohidrat sebesar $60 \%$ diikuti dengan lemak dan protein. Karbohidrat utama pada jagung hibrida adalah pati yang terdiri dari amilosa (1000 unit glukosa) 70 - 75\% dan amilopektin (lebih dari 40.000 unit glukosa). Jagung normal mengandung amilosa sekitar $27 \%$ dan amilopektin sekitar $73 \%$. Keduanya merupakan polimer dengan berat molekul yang tinggi. Polimer tersebut tersusun dari unit-unit D-glukosa. Sukrosa merupakan komponen gula utama pada jagung. Sukrosa terdapat pada bagian lembaga sebanyak $75 \%$ dan bagian endosperm sebanyak $25 \%$. Biji jagung jugan mengandung serat kasar sebanyak 2,1 - 2,3\% terdiri 41 - 46\% hemiselulosa di dalam kulit ari (Inglet 1970 diacu dalam Lopulalan 2008).

Komposisi kimia jagung bervariasi antara varietas yang berbeda maupun untuk varietas yang sama pada tanaman yang berbeda, dapat dilihat dalam tabel 2.1. Hal ini disebabkan oleh proses pembentukan jagung sebagai organ penyimpan makanan dipengaruhi oleh beberapa faktor, antara lain faktor genetis seperti spesies, varietas, dan keturunan; faktor lingkungan seperti keasaman, kandungan air, pemupukan, makanan, dan lain-lain; faktor perlakuan seperti metode dan cara panen, pembibitan, pengolahan, dan penyimpanan. 


\section{Jagung Putih}

Taksonomi dan nama spesies jagung putih sama dengan jagung kuning (Zea mays L.), perbedaannya adalah pigmen carotenoid tidak terdapat pada jagung putih. Jagung putih adalah tanaman berumah satu, yaitu malai (bunga jantan) dan rambut (bunga betina) terletak pada satu tanaman. Tipe biji jagung putih umumnya adalah mutiara (flint corn), biji seperti mutiara, gembung dan keras. Jagung putih pulut (waxy corn) merupakan varian dari jagung putih. Status jagung putih pulut oleh sebagian petani di Sulsel, NTB, NTT dan Maluku dianggap sama sebagai jagung putih. Petani menanam jagung putih pulut untuk dipanen muda, dimakan dalam bentuk rebusan (Pasireron, Sirappa, \& Dahamarhudin, 2013). Jagung putih pulut berwarna putih bening, berumur genjah 85 hari serta mengandung amilosa rendah $(<10 \%)$ dalam endosperm biji.

Di Indonesia jagung putih banyak ditanam di NTT dan NTB dalam usaha tani monokultur dan campuran (mixed cropping). Petani jagung di Indonesia terutama masyarakat perdesaan kawasan timur Indonesia (KTI), banyak mengonsumsi biji jagung putih sebagai makanan pokok, ditanak bersama beras dalam bentuk nasi - jagung. Jagung putih mengandung nutrisi yang melebihi nutrisi jagung kuning, bertekstur pulen, enak, dan mempunyai ketahanan terhadap kekeringan (Yusuf \& Syamsuddin, 2013). Secara morfologis dan genomik jagung putih $99 \%$ serupa dengan jagung kuning. endosperm, 2/3 biji jagung terdiri atas selsel muatan tepung, jika tidak terdapat pigment carotenoid maka biji berwarna putih.

\section{Edible/Coating Film}

Edible Film adalah suatu lapisan tipis yang terbuat dari bahan-bahan yang dapat dimakan, dibentuk di atas komponen makanan (coating) atau diletakkan antara komponen makanan (film) yang berfungsi sebagai penghalang terhadap transfer berat (misalnya, kelembaban, oksigen, lipid dan zat terlarut) (Hui, 2006). Bahan- bahan yang biasa digunakan dalam pembentukan edible film adalah protein, polisakarida, lemak, wax dan turunannya. Edible film dan biodegradable film banyak digunakan untuk pengemasan produk buah - buahan segar yaitu untuk mengendalikan laju respirasi, akan tetapi produk -produk pangan lainnya juga sudah banyak menggunakan edible coating, seperti produk daging dan ayam beku, sosis, produk hasil laut dan pangan semi basah. Edible film juga dapat diaplikasikan pada snack atau crackers yang diberi bumbu, yaitu sebagai pengikat atau adhesif ${ }^{1}$ dari bumbu yang diberikan agar dapat lebih melekat pada produk. Pelapisan ini berguna untuk mengurangi lemak pada bahan yang digoreng dengan penambahan bumbu - bumbu.

Komponen utama penyusun edible film dapat digolongkan kedalam tiga kategori, yaitu hidrokoloid, lipid, dan komposit (gabungan hidrokoloid dan lipid). Hidrokoloid dapat berupa protein, turunan selulosa, alginat, pektin, pati dan polisakarida lain. Lipid yang umum digunakan antara lain lilin (wax), gliserol, dan asam lemak. Edible film dengan komponen campuran komposit dapat berupa film emulsi lipid hidrokoloid atau beberapa bilayer film dengan satu muka film hidrofilik dan muka lain yang hidrofobik. Film dari bahan dasar lipid mempunyai laju transmisi uap air dan kekuatan mekanik yang rendah, sedangkan protein dan karbohidrat bersifat kuat tapi laju transmisi uap airnya tinggi. Komposit film yang merupakan gabungan dari protein dan lipid atau gabungan dari karbohidrat dan lipid, mempunyai laju transmisi yang lebih rendah dibandingkan film dengan bahan dasar protein dan karbohidrat, tapi memiliki kekuatan mekanik yang lebih kuat dibandingkan film yang berbahan dasar lipid.

(Iwata, Ishaki, Handa, \& Tanaka, 2000) menyatakan protein sebagai komponen penyusun edible film memiliki banyak kelebihan diantaranya protein mengandung asam-asam amino yang dibutuhkan tubuh, dan edible film yang dihasilkan dari bahan dasar protein dapat digunakan untuk mengurangi kehilangan kelembaban, membatasi absorpsi oksigen, dan mengurangi perpindahan lemak. Pada umumnya edible film yang terbuat dari polisakarida (hidrokoloid) mempunyai sifat penghambatan terhadap gas yang lebih baik daripada terhadap uap air (Baldwin et al, 1995 dalam Jacob, Nugraha, \& Utari, 2014). Edible film yang larut dalam air memiliki penghalang lebih buruk dibandingkan dengan edible film yang larut dalam pelarut selain air. Hal ini terjadi karena uap air tidak dapat larut dengan cepat pada edible film yang larut dalam pelarut selain air. Menurut Krochta (1994), permeabilitas dipengaruhi oleh sifat kimia bahan, struktur polimer, kondisi uji, dan sifat dari bahan yang akan berdifusi. Untuk memperbaiki sifat tersebut biasanya polisakarida dikombinasikan dengan beberapa pangan fungsional yaitu resin, platicizer, surfaktan, minyak, lilin dan emulsifier yang memiliki fungsi memberikan permukaan yang halus dan mencegah kehilangan uap air.

\section{Gliserol}

Plasticizer adalah bahan organik dengan berat molekul rendah yang ditambahkan agar memperlemah kekakuan film (Gennadios, 2002). Plasticizer memiliki titik didih yang tinggi dan jika ditambahkan ke dalam suatu materi dapat mengubah

\footnotetext{
${ }^{1}$ Adhesive adalah sifat tarik menarik antar molekul yang berbeda jenis
} 
sifat fisik maupun sifat mekanik materi. Penggunaan plasticizer dapat mengurangi gaya intermolekul sepanjang rantai polimer, sehingga meningkatkan fleksibilitas edible film tetapi mengakibatkan turunnya permeabilitas film. Bahan ini larut dalam tiap - tiap rantai polimer sehingga akan mempermudah gerakan molekul polimer dan bekerja menurunkan suhu transisi gelas, suhu kristalisasi, atau suhu pelelehan dari suatu polimer (Sperling, 1992). Kester \& Fennema, (1986) menyatakan bahwa plasticizer dapat ditambahkan pada pembuatan edible coating, untuk mengurangi kerapuhan, meningkatkan fleksibilitas, dan ketahanan film terutama jika disimpan pada suhu rendah.

Jenis plasticizer yang biasanya digunakan antara lain, gliserin, gliserol, trietil, glikol, asam lemak, dan monogliserin yang diasetilisasi. Namun plasticizer yang sering digunakan adalah gliserol. Plasticizer ini merupakan senyawa alkohol polianhidrat dengan tiga gugus hidroksil dalam satu molekul. Rumus kimia gliserol adalah $\mathrm{C}_{3} \mathrm{H}_{8} \mathrm{O}_{3}$ dengan nama 1,2,3-propanatriol. Berat molekul gliserol adalah 92,10 g/mol dan titik didih sebesar $204{ }^{\circ} \mathrm{C}$ (Winarno, 2008). Gliserol efektif digunakan sebagai plasticizer pada hidrofilik film. Penambahan gliserol akan mengahasilkan film yang lebih fleksibel dan halus. Menurut Gontard, Guilbert, \& Cuk (1993) gliserol dapat meningkatkan permeabilitas film terhadap uap air. Gliserol mempunyai sifat mudah larut dalam air, meningkatkan kekentalan larutan, mengikat air dan menurunkan aktifitas kadar air (Linsay, 1985). Selain itu gliserol juga bersifat humektan ${ }^{2}$ dan bagian dari aksi plasticizing yang berasal dari kemampuannya untuk menahan air pada film tersebut (Kristanoko, 2000).

\section{Karagenen}

Karagenen merupakan senyawa hidrokoloid yang diekstrak dari rumput laut spesies tertentu dari kelas rhodophyceace (rumput laut merah). Karagenen merupakan hasil metabolisme primer dari rumput laut sebagai senyawa polisakarida yang disusun dari sejumlah unit galaktosa dengan ikatan $\alpha(1,3)$ D-galaktosa dan $\beta$ $(1,4)$ 3,6-anhidrogalaktosa secara bergantian, baik yang mengandung ester sulfat atau tanpa sulfat. Karagenen memiliki sifat sebagai gelling agent yang dipengaruhi oleh faktor antara lain $\mathrm{pH}$, stabilitas, viskositas, pembentukan gel dan reaktifitas dengan protein, sehingga karagenen banyak dimanfaatkan sebagai stabilisator, thickener, pembentuk gel dan pengemulsi yang digunakan dalam bidang industri

\footnotetext{
${ }^{2}$ Humektan: bahan yang dapat mempertahankan kelembaban
}

makanan, obat-obatan, tekstil, kosmetik dan industri lainnya (Voulda, 2010).

Penggunaan karagenen dalam jumlah yang lebih besar menyebabkan kemampuan mengikat air yang lebih baik sehingga memberikan matrik gel yang dapat meningkatkan sifat mekanik dari pengemas. Menurut Carriedo (1994), gel yang dihasilkan dari karagenan dapat digunakan dalam pelapisan makanan. Dalam bidang industri karagenen berfungsi sebagai stabilisator, thickener (bahan pengental), pembentuk gel dan lain-lain. Beberapa sifat yang berperan penting dalam karagenen antara lain; kelarutan, stabilitas $\mathrm{pH}$, pembentukan gel, dan viskositas. Karagenan larut dalam air, kelarutannya dipengaruhi oleh beberapa faktor, yaitu tipe karagenan, pengaruh ion, suhu, komponen organik larutan, dan $\mathrm{pH}$. Semua karagenan larut dalam air panas terutama pada suhu $>70^{\circ} \mathrm{C}$. Dalam air dingin hanya lamda - karagenan, garam sodium dari kappa-karagenan, dan iotakaragenan yang dapat larut (Glicksmen, 1998). Karagenen adalah senyawa yang bersifat hidrokoloid. Kelebihan karagenen sebagai edible film yaitu dapat membentuk gel yang baik, elastis, dapat dimakan dan dapat diperbaharui, tetapi edible film dari karagenen juga memiliki kelemahan yaitu kemampuan yang rendah sebagai barrier terhadap transfer uap air, sehingga membatasi pemanfaatannya sebagai kemasan (Handito D., 2011).

Penelitian-penelitian yang telah dilakukan sebelumya megemukakan bahwa dengan penambahan volume gliserol berpengaruh terhadap nilai kekuatan tarik dan pemanjangan saat putus dari bioplastik. Seiring bertambahnya volume gliserol maka nilai kekuatan tarik akan semakin menurun, sebaliknya nilai pemanjangan akan semakin meningkat. Penambahan karagenen beberapa pati seperti pati umbi talas dan pati jagung juga memberikan pengaruh terhadap sifat fisik serta mekanik dari edible film. Akhhirnya dalam penelitian ini terfokus pada pembuatan edible film berbahan dasar tepung jagung putih, gliserol dan karagenen serta analisis kualitas dan kuatitasnya. Bahan baku edible film berupa jagung putih dari Sumbawa juga menjadi bahan baru untuk dikaji, dan ini cukup menarik sebab jagung merupakan bagian pijar $^{3}$.

\section{MATODE PENELITIAN}

Penelitian yang bersifat eksperimental ini telah dilaksanakan sejak bulan Maret hingga September 2019 di laboratorium pangan terpadu FATETA UTS, bekerja sama dengan laboratorium kimia organik Universitas Gadjah Mada,

\footnotetext{
${ }^{3}$ Pijar: sebutan pemda kabupaten Sumbawa untuk program sapi jagung rumput laut (potensi lokal Sumbawa).
} 
laboratorium analisis pangan Politeknik Negeri Jember, serta laboratorium pengujian mutu dan keamanan pangan Universitas Brawijaya Malang.

Adapun alat - alat yang digunakan yaitu: baskom, spatula, penepung jagung, ayakan, toples, cawan petri, gelas ukur, termometer, timbangan analitik, penjepit, labu takar, pipet tetes, pipet volume, bola hisap, oven, hot plate stirrer, magnet bar, FTIR, desikator, tanur, jangka sorong, plastic wrap, kertas nasi, kertas label, tisu, penggaris, gunting, kamera untuk dokumentasi penelitian dan alat tulis. Sementara bahan yang digunakan dalam penelitian ini adalah: jagung putih dari Pasar Induk Seketeng Kabupaten Sumbawa, ragi tape dari Desa Pelat, Kecamatan Moyo Hulu, natrium metabisulfit, akuades, gliserol, karagenan.

\section{Pembuatan Tepung Jagung Putih (Akbar \& Yunianta, 2014).}

Tepung jagung putih dibuat dengan cara (a) $1 \mathrm{~kg}$ biji jagung direndam beberapa jam kemudian ditepungkan dan dikeringkan kembali dalam oven suhu $30{ }^{\circ} \mathrm{C}$, (b) $1 \mathrm{~kg}$ biji jagung direndam dalam natrium metabisulfit 100 ppm sebanyak $1: 2$ selama 3 hari, difermentasi menggunakan $1 \%$ ragi tape selama 24 jam, kemudian ditepungkan serta dioven dan diayak. Kedua jenis tepung jagung dilakukan uji proksmat dan dikaraterisasi menggunakan FTIR. Hasil terbaik dari kedua jenis perlakukan (a) dan (b) dijadikan bahan baku edible film.

\section{Pembuatan Edible Film (Rusli, Metusalach, Salengke, \& Tahir, 2017)}

Tepung jagung sebanyak $3 \mathrm{~g}$ dilarutkan dalam $100 \mathrm{~mL}$ akuades, dipanaskan hingga suhu kurang lebih $85^{\circ} \mathrm{C}$ sambil diaduk pada lingkungan terbuka. Kemudian ditambahkan karagenan dengan variasi konsentrasi $(1 \%, 2 \%$ dan 3\%) dan diaduk hingga homogen. Didiamkan hingga suhu $60^{\circ} \mathrm{C}$, kemudian ditambahkan gliserol dengn variasi konsentrasi $(5 \%, 10 \%$ dan 15\%). Suspensi dicetak, didiamkan selama 24 jam kemudian dioven suhu 40 oC selama 5 jam. Setelah kering, didinginkan dalam ruang terbuka sampai suhunya sama dengan suhu ruangan. Lapisan film selanjutnya dilakukan uji warna, kuat tarik, pemanjangan dan FTIR.

Analisis sifat Fisik (Akesowan, 2010 dalam Mulyadi, Pulungan, \& Qiyyum, 2016)

\section{Analisa Kecerahan}

Disiapkan edible film. Diukur nilai $\mathrm{L}$ (kecerahan), a(kemerahan) dan b (kekuningan) pada film menggunakan alat colour reader. Dihitung perbedaan total kecerahan $(\Delta \mathrm{E})$, indeks kekuningan (YI) dan indeks keputihan (WI) menggunakan persamaan:

$\Delta \mathrm{E}=\left(\Delta \mathrm{L}^{2}+\Delta \mathrm{a}^{2}+\Delta \mathrm{b}^{2}\right)^{1 / 2}$

$\mathrm{YI}=142,86 \mathrm{~b} / \mathrm{L}$

$\mathrm{WI}=100-\left[(100-\mathrm{L})^{2}+\mathrm{a}^{2}+\mathrm{b}^{2}\right]^{1 / 2}$

\section{Analisis Sifat Mekanik Kuat tarik (Setiani,} Sudiarti, \& Rahmidar, 2013)

Pengujian kuat tarik dilakukan dengan memotong sampel edible film dengan ukuran $15 \mathrm{~cm} \times 1 \mathrm{~cm}$. kemudian edible film dijepit $\pm 5 \mathrm{~cm}$ dikedua sisi panjangnya lalu di uji dengan menggunakan alat texture analyzer (TA Plus-Lloyd Instruments). Tensile strength dihitung dengan persamaan :

\section{Tensile Strength}

$$
\begin{aligned}
& =(\text { F maksimum }) \\
& /(\text { Luas Permukaan }(A))
\end{aligned}
$$

Ket :

F maksimum : Gaya maksimum (N)

A : Luas Permukaan edible Film $(\mathrm{cm} 2)$

Pengukuran Persentase Pemanjangan (Setiani, Sudiarti, \& Rahmidar, 2013)

Pengujian persentase pemanjangan dilakukan dengan memotong sampel edible film dengan ukuran $15 \mathrm{~cm} \times 1 \mathrm{~cm}$ kemudian edible film dijepit $\pm 5 \mathrm{~cm}$ dikedua sisi panjangnya lalu di uji dengan menggunakan alat texture analyzer (TA Plus- Lloyd Instruments). Persentase pemanjangan dihitung dengan persamaan :

$$
\% \text { Elongasi }=(A-B) / B \times 100 \%
$$

Ket :

A : panjang setelah putus

B : panjang sebelum putus

\section{Rancangan Percobaan}

Rancangan percobaan yang digunakan pada kegiatan penelitian ini adalah RAK (Rancangan Acak Kelompok) dengan 2 faktor yaitu konsentrasi gliserol $(5 \%, 10 \%$, dan $15 \%)$ dan konsentrasi karagenan $(1 \%, 2 \%$ dan $3 \%)$ sehingga terdapat 9 unit percobaan

\section{HASIL DAN PEMBAHASAN}

\section{Analisis Tepung Jagung Putih}

Bahan baku jagung putih berasal dari pasar lokal Seketeng, Kota Sumbawa, Provinsi NTB. Dalam proses pembuatan tepung jagung, biji jagung disortasi, direndam dalam sodium metabisulfit, dicuci, difermentasi, dikeringkan kemudian ditepungkan. Perendaman dalam sodium metabisulfit bertujuan mencegah proses pencoklatan bahan, sehungga semakin lama dilakukan perendaman semakin cerah tepung jagung yang dihasilkan Angelia \& Hasan (2018) dan Akbar \& Yunianta (2014)
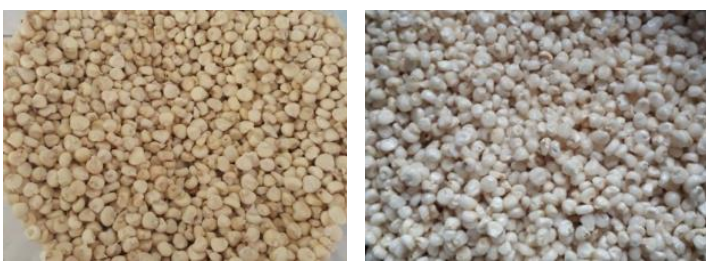
(a)

(b)

Gambar 2. Jagung (a) sebelum dan (b) setelah perendaman dalam $\mathrm{Na}_{2} \mathrm{SO}_{2} \mathrm{O}_{5}$

Gambar 1 menunjukkan perbedaan warna jagung sebelum perendaman yakni putih tulang dan pucat, namun setelah direndam dalam natrium metabsulfit $\left(\mathrm{Na}_{2} \mathrm{SO}_{2} \mathrm{O}_{5}\right)$ menjadi putih. Natrium metabisulfit dapat mengambat terbentuknya meladonin (pigmen coklat). Meladonin merupakan polimer dengan berat molekul besar yang dapat terbentuk dari proses termal molekul karbohidrat dan asam amino (Chang et all, 2015). Sifat basa natrium metabisulfit dapat meningkatkan $\mathrm{pH}$ asam amino menghambat pembentukan pigmen meladonin.

Selain merubah warna, perendaman juga menghasilkan aroma menyengat yang serupa dengan natrium metabisulfit. Penguraian natrium mebisulfit dalam air dapat menghasilkan sulfur dioksida $\left(\mathrm{SO}_{2}\right)$ yang baunya menyengat, bau tersebut berkurang dengan cara pencucian. Jagung yang telah diputihkan kemudian difermentasi menggunakan ragi tape yang diperoleh dari Desa Pernek (desa penghasil ragi di Kabupaten Sumbawa). Berbagai manfaat fermentasi jagung antara lain: (a) mengurangi kadar asam fitat dalam jagung melalui reaksi ezimatis (Susilawati, Syam, \& Fadhilah, 2018; Arief, Irawati, \& Yusmasari, 2011), sehingga dapat meningkatkan nilai cerna pati dan protein. Asam fitat dalam jagung menyebabkan beberapa mineral dan protein menjadi tidak terlarut sehingga sulit dicerna. Oleh karena itu asam fitat dianggap sebagai antinutrisi pada bahan pangan. Secara alami, fitat membentuk komplek dengan beberapa mineral (P, Zn, Fe, Mg, Ca), protein, dan asam amino. Adanya mikroorganisme dalam ragi tape dapat menghaslkan enzim fitase yaitu enzim yang dapat menghidrolisis asam fitat menjadi senyawa yang larut dalam air (Arief, Irawati, \& Yusmasari, 2011). Diantara tanaman serealia lainnya, jagung memiliki kandungan asam fitat tertinggi (Claudia dkk, 2015). Fermentasi juga mengubah aroma menyengat natrium metabisulfit pada biji jagung berubah menjadi aroma alkohol. Alkohol merupakan produk dalam reaksi fermentasi pati seperti yang terlihat dalam Gambar 2 .

Perbedaan warna tepung jagung sebelum dan setelah fermentasi terlihat dalam Gambar 3, sementara hasil uji proksimat (karbohidrat, lemak, protein, abu, air), pati, amilosa dan amilopektin disajikan dalam Tabel 1. Jika dibandingkan dengan SNI, baik tepung jagung A maupun B memiliki kadar air diatas batas maksimum SNI yakni $10 \%$. Jika dibandingkan dengan tepung jagung komersil (C), kadar air tepung jagung A lebih tinggi namun tepung jagung B tertinggi. Kadar air yang banyak disebabkan oleh adanya proses perendaman jagung dalam air dan natrium metabisulfit sebelum ditepungkan. Hidrolisis karbohidrat dalam jagung juga menjadi faktor tingginya kadar air dalam tepung jagung, sehingga air menjadi terperangkap dalam molekul pati. Tingginya kadar air dalam tepung jagung berdampak pada umur simpannya, tepung jagung mulai bau dan terlihat menggumpal di hari ke 53.

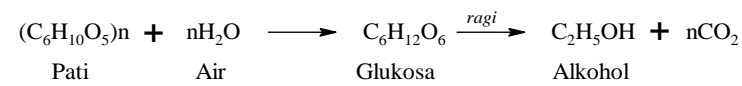

Gambar 3. Reaksi fermentasi jagung

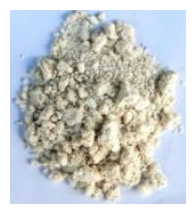

A

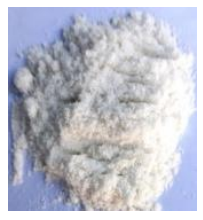

B

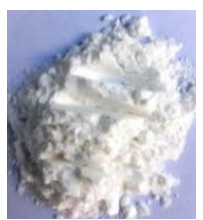

$\mathrm{C}$
Gambar 4. Tepung jagung (A) tanpa perlakuan (B) fermentasi (C) komersil

Kadar abu tepung jagung B paling rendah daripada tepung jagung A dan tepung jagung C. Abu dalam tepung jagung mengandung mineral seperti seng $(\mathrm{Zn})$ dan Tembaga $(\mathrm{Cu})$. Rendahnya kadar abu dalam tepung jagung $\mathrm{B}$ disebabkan oleh perendaman dalam natrium metabisulfit. Gas $\mathrm{SO} 2$ dapat membentuk garam sulfat yang dapat berikatan dengan kation berupa $\mathrm{Zn}$ maupun $\mathrm{Cu}$ dalam jagung. Selanjutnya tembaga (II) sulfat dan seng (II) sulfat dapat terlepas saat dibilas, karena sifatnya larut dalam air.

Kadar protein, lemak, karbohidrat, pati, amilosa dan amilopektin tepung jagung B paling rendah dibandingkan tepung jagung A dan C. Hal ini mengindikasikan bahwa proses perendaman dalam natrium metabisulfit serta fermentasi telah menguraikan senyawa makro molekul organik yang terdapat dalam jagung. Protein yang bersifat amfoter dapat terdenaturasi oleh basa metabisulfit, dapat pula terdenaturasi oleh asam hasil fermentasi. Sementara karbohidrat (pati, amilosa, amiopektin) mengalami hidrolisis dikatalis oleh ragi tape menjadi glukosa dan alkohol. Pati jagung memiliki amilosa yang lebih banyak dari pada amilopektin. (Susilawati, Syam, \& Fadhilah, 2018). Menurut (Winarno, 2008) lemak juga dapat teridrolisis menjadi gliserol dan asam lemak bebas saat perendaman dalam air. Adanya perombakan molekul - molekul organic oleh mikroorganisme menyebabkan penurunan kadar komponen (Aini, Wijonarko, \& Sustriawan, 2016). Warna tepung jagung fermentasi (B) dan tanpa perlakuan (A) dilakukan menggunakan tepung jagung komersil (C) sebagai control. Hasilnya menunjukkan bahwa tepung jagung B memiliki indeks keputihan (WI) bernilai positif (putih), agak kuning dan lebih cerah dari control. Sementara tepung jagung A berwarna 
lebih hitam dari standar, lebih biru dari standard dan gelap. Jika dibandingkan degan SNI, tepung jagung yang berkwalitas adalah memiliki warna putih cerah atau mendekati warna tepung jagung komersil. Sehingga tepung yang dipilih untuk dijadikan bahan baku edible film adalah tepung jagung B dengan perlakuan perendaman dalam natrium metabisulfit dan fermentasi.

Tabel 1. Uji proksimat, pati, amilosa dan amlopektin tepung jagung

\begin{tabular}{|llll|}
\hline & \multicolumn{3}{c|}{ Tepung Jagung } \\
\cline { 2 - 4 } Uji & $\begin{array}{l}\text { Tanpa } \\
\text { Perlakuan } \\
\text { (A) }\end{array}$ & $\begin{array}{l}\text { Fermentasi } \\
\text { (B) }\end{array}$ & $\begin{array}{l}\text { Komersil } \\
\text { (C) }\end{array}$ \\
\hline Air (\%) & 12,61 & 25,34 & 12,46 \\
Abu (\%) & 0,72 & 0,42 & 0,70 \\
Lemak (\%) & 0,08 & 0,04 & 0,08 \\
Protein (\%) & 0,41 & 0,38 & 0,44 \\
Karbohidrat & 86,17 & 74,04 & 86,55 \\
$\begin{array}{l}\text { (\%) } \\
\text { Amilosa }\end{array}$ & 55,40 & 47,90 & 55,71 \\
$\begin{array}{l}\text { Am) } \\
\text { Amilopektin }\end{array}$ & 19,84 & 17,39 & 19,82 \\
$(\%)$ & 77,30 & 66,33 & 77,59 \\
Pati (\%) & & & \\
\hline
\end{tabular}

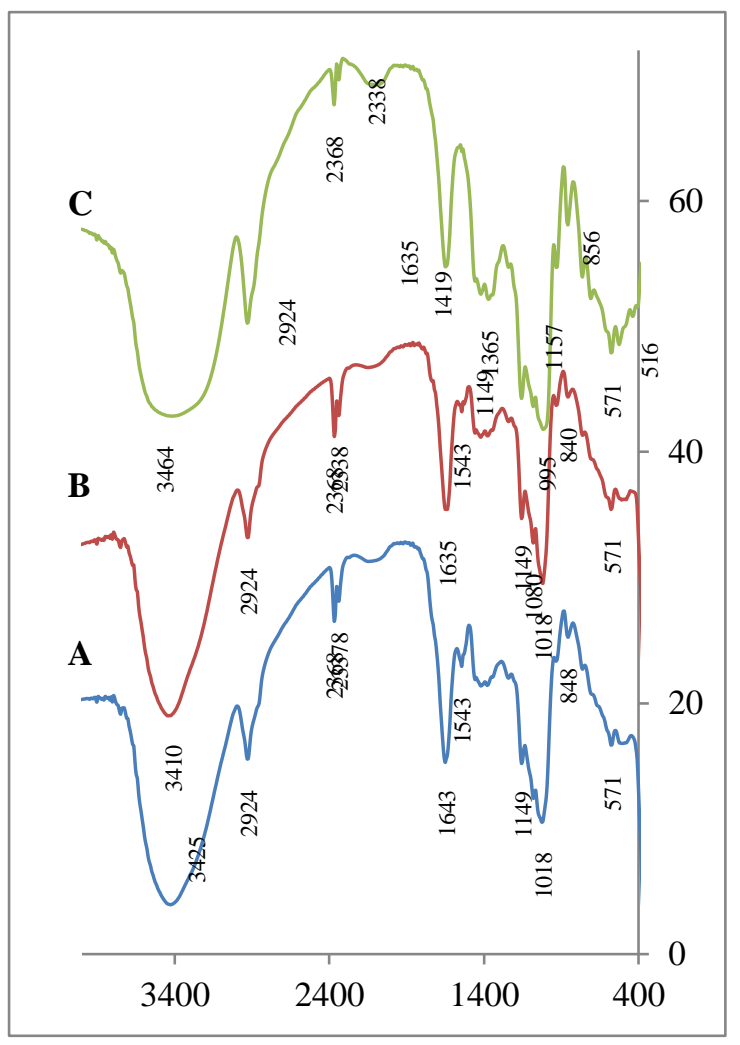

Gambar 5. Spektra IR tepung jagung (A) tanpa perlakuan (B) fermentasi (C) komersil

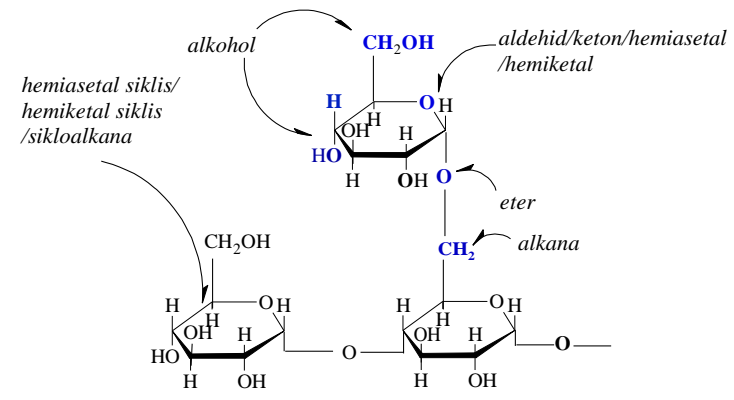

Gambar 6. Gugus fungsi molekul karbohidrat tepung jagung

Hasil uji FTIR baik pada tepung jagung tanpa perlakuan maupun tepung jagung fermentasi tidak memiliki perbedaan spektra IR yang signifikan. Hal tersebut karena komposisi gugus fungsi kedua tepung sama. Gugus fungsi kedua tepung diambil dari senyawa yang dominan yakni karbohidrat. Berdasarkan gambar 5 adapun gugus fungsi yang terdapat dalam molekul karbohidrat terdiri dari: alkohol, sikloalkana, hemiketal, hemiasetal, alkana dan eter. Gugus fungsi tersebut dapat terbaca melalui peak dalam spektra IR pada gambar 4.

Dibandingkan dengan kedua tepung jagung $\mathrm{A}$ dan $\mathrm{B}$, tepung jagung $\mathrm{C}$ memiliki peak melebar. Hal tersebut menunjukkan bahwa vibrasi $\mathrm{O}-\mathrm{H}$ dalam tepung jagung $\mathrm{C}$ lebih lemah. Meski demikian, baik tepung $\mathrm{A}, \mathrm{B}$ maupun $\mathrm{C}$ memiliki \% $\mathrm{T}$ yang relatif sama. Hal ini mengindikasikan bahwa jumlah konsentrasi $\mathrm{O}-\mathrm{H}$ dalam tepung juga sama. Keberadaan vibrasi molekul $\mathrm{O}-\mathrm{H}$, juga didukung oleh munculnya peak pada bilangan gelombang $2368 \mathrm{~cm}^{-1} 2338 \mathrm{~cm}^{-1}, 1180 \mathrm{~cm}^{-1}, 1018 \mathrm{~cm}^{-1}, 1149 \mathrm{~cm}^{-}$

Ketiga spektra memiliki peak pada bilangan gelombang $3000 \mathrm{~cm}^{-1}-2840 \mathrm{~cm}^{-1}$ yang mengindikasikan keberadaan molekul alkana $(\mathrm{C}-$ $\mathrm{H}), \% \mathrm{~T}$ nya pun tidak jauh berbeda, indikasi bahwa konsentrasi gugus fungsi tersebut juga sama. Keberadaan gugus fungsi alkana juga diperkuat oleh munculnya berbagai peak pada bilangan gelombang $2924 \mathrm{~cm}^{-1}, 2854 \mathrm{~cm}^{-1}$ dan $1543 \mathrm{~cm}^{-1}, 1419 \mathrm{~cm}^{-1}, 894$ $\mathrm{cm}^{-1}, 571 \mathrm{~cm}^{-1}$ di tepung A dan B.

Gugus keton maupun aldehid meruakan karakteristik dari molekul karbohidra. Baik keton maupun aldehid dapat menjadi senyawa hemiketal siklik dan hemiasetal siklis melalui reaksinya denagn alcohol. Keberadaan senyawa keton dan aldehid pada ketiga tepung terlihat dalam spectra IR melalui peak $1643 \mathrm{~cm}^{-1}$ dan $1636 \mathrm{~cm}^{-1}$. Diperkuat oleh munculnya peak pada bilangan gelombang $1080 \mathrm{~cm}^{-1}, 1018 \mathrm{~cm}^{-1}$ yang menujukkan adanya senyawa siklisnya. Menurut Siregar, Santoso, \& Uju, (2016) Vibrasi pada bilangan gelombang 1010 $\mathrm{cm}^{-1}-1080 \mathrm{~cm}^{-1}$ serta diperkuat oleh adanya peak $1066 \mathrm{~cm}^{-1}$ pada sampel ketiga jenis tepung merupakan indikasi vibrasi ikatan glikosidik 


\section{Analisis Edible Film Tepung Jagung Putih} Termodifikasi Gliserol dan Karagenan

Bahan baku pembuatan edible film adalah tepung jagung B, karagenan dan gliserol, Tepung jagung telah diketahui mengandung karbohidrat, lemak, protein dan mineral, diantara komponen tersebut, karbohidrat paling dominan. Baik amilosa maupun amilopektin memiliki sruktur kimia yang mirip dengan karagenan sehingga tepung jagung dapat mengurangi jumlah pemakaian karagenan. Larutan tepung jagung berwarna putih (warna dari pati), semakin lama dipanaskan akan mengental dan berwarna putih pucat, Hal tersebut menunjukkan bahwa kandungan pati didalamnya mengalami gelatinisasi, Menurut Dewi (2011),

kadar amilosa dalam pati berpengaruh dalam pembentukan gel yang kuat dan kaku, Amilosa bila dilarutkan dalam air, sangat tidak stabil dan cepat membentuk gelatin, sedangkan amilopektin sangat efektif mencegah terjadinya granula pecah akibat gelatinisasi, Gelatinisasi terbentuk, akhirnya membentuk granula pada saat pemanasan, mengakibatkan kadar air semakin turun dengan bertambahnya amilosa dan amilopektin, Amilosa berperan dalam kelenturan dan kekuatan edible film. Selain itu pati jagung mengandung zein yang memiliki kemampuan untuk membentuk film yang kaku, mengkilap, tahan lecet, dan tahan lemak (Amaliya dan Widya, dalam Saragih, Restuhadi, \& Rossi, 2016)

Penambahan karagenan dalam larutan tepung jagung menjadikan larutan semakin kental dan mengurangi kecepatan magnet bar saat pengadukan, Semakin banyak karagenan yang diambahkan, larutan menjadi semakin pekat, Jika terlalu lama didiamkan suspensi dapat memadat sebelum dicetak. Karagenan merupakan padatan yang berwarna putih, jika dilarutkan dalam air panas terlihat mengental dan mudah gosong (coklat).

Edible film yang dibuat dari tepung jagung dan karagenan disebut sebagai edible film kontrol (C), Variasi karagenan pada kontrol adalah $1 \% ; 2 \%$; dan $3 \%$ yang masing masing disebut sebagai $\mathrm{C} 1$; C2; dan C3. Edible film dengan jumlah kargenan semakin banyak menyebabkan lapisan terlihat tebal, keras, mudah retak, pengeringannya pun semakin lama. Ketebalan lapisan film ditandai dengan permukaan film yang sulit melengkung, sementara permukaan yang tipis sangat mudah melengkung ke atas. Perbedaan permukaan tebal dan tipis terihat pada C1 dan C3. Menurut Saragih, Restuhadi, \& Rossi, (2016) penggunaan karagenen yang semakin banyak akan meningkatkan transparansi dan membenuk gel yang baik pada edible film.

Diantara ketiga sampel, edible film G10\% K3\% memiliki bobot paling berat, paling sulit dicetak sebab cepat memadat, namun setelah kering paling mudah diangkat dan mudah dibentuk,
Jika pengeringan tidak maksimal, edible film dengan komposisi 3\% karagenen dapat berjamur, Menurut Apriwijaya (2018) karagenan mampu mengikat air dan protein, semakin banyak karagenan yang ditambahkan semakin tinggi kadar air dalam bahan, Komplek karagenan dengan protein disebut sebagai proteokaragenan. Sifat karagenan yang suka air dapat memicu pertumbuhan jamur. Untuk mencegah terbentuknya jamur, edible film harus disimpan di tempat kering.

Modifikasi edible film dilakukan dengan penambahan gliserol bertujuan mengahasilkan film yang lebih fleksibel dan halus (Saragih, Restuhadi, \& Rossi, 2016), Adanya gliserol pada edible film menyebabkan lapisan terlihat lebih lentur dan mudah diangkat dari cetakan, sementara tanpa gliserol (hanya karagenan), lapisan sangat sulit dingakat dari cetakan, mudah retak. Semakin banyak gliserol yang ditambahkan lapisan film semakin lentur, terlihat semakin berminyak dan halus. Permukaan berminyak disebabkan adanya kandungan lemak pada tepung jagung, dan gliserol dapat bereaksi dengan asam lemak pada jagung menjadi trigliserida atau lemak.

\section{Karaktrisasi Edible Film menggunakan FTIR}

Karakterisasi edible film menggunakan FTIR bertujuan mengetahui pengaruh karagenan dan gliserol. Molekul gliserol tersusun dari $\mathrm{OH}$ alkohol, $\mathrm{CH}_{2}$ dan $\mathrm{CH}_{3}$ alkana. Sementara karagenan memiliki gugus sulfat dan ikatan glikosidik yang serupa amilosa serta amilopektin. Adapun spektra IR disajikan dalam gambar 6 .

Peak terlihat berbeda pada $\mathrm{C} 2$ dan G5\% $2 \%$. Gliserol menyebabkan peak G5\% $2 \%$ terlihat lebih melebar dan landai $3400-3300 \mathrm{~cm}^{-1}$. Hal ini menunjukkan vibrasi molekul $\mathrm{OH}$ semakin lemah saling overlap antara gugus $\mathrm{OH}$ pada tepung jagung, karagenan maupun gliserol. Ikatan hidrogen yang kuat pada molekul gliserol, karagenan dan tepung jagung juga memberikan pengaruh terhadap lemahnya vibrasi ikatan $\mathrm{O}-\mathrm{H}$ yang sama-sama terdeteksi pada peak yang landau pada bilangan gelombang $3400-2400 \mathrm{~cm}^{-1}$. Vibrasi pada bilangan gelombang $1010 \mathrm{~cm}^{-1}-1080 \mathrm{~cm}-1$ serta diperkuat oleh adanya peak $1066 \mathrm{~cm}^{-1}$ pada sampel C2; G5\% $2 \%$ dan Karagenan merupakan indikasi vibrasi ikatan glikosidik (Siregar, Santoso, \& Uju, 2016) 


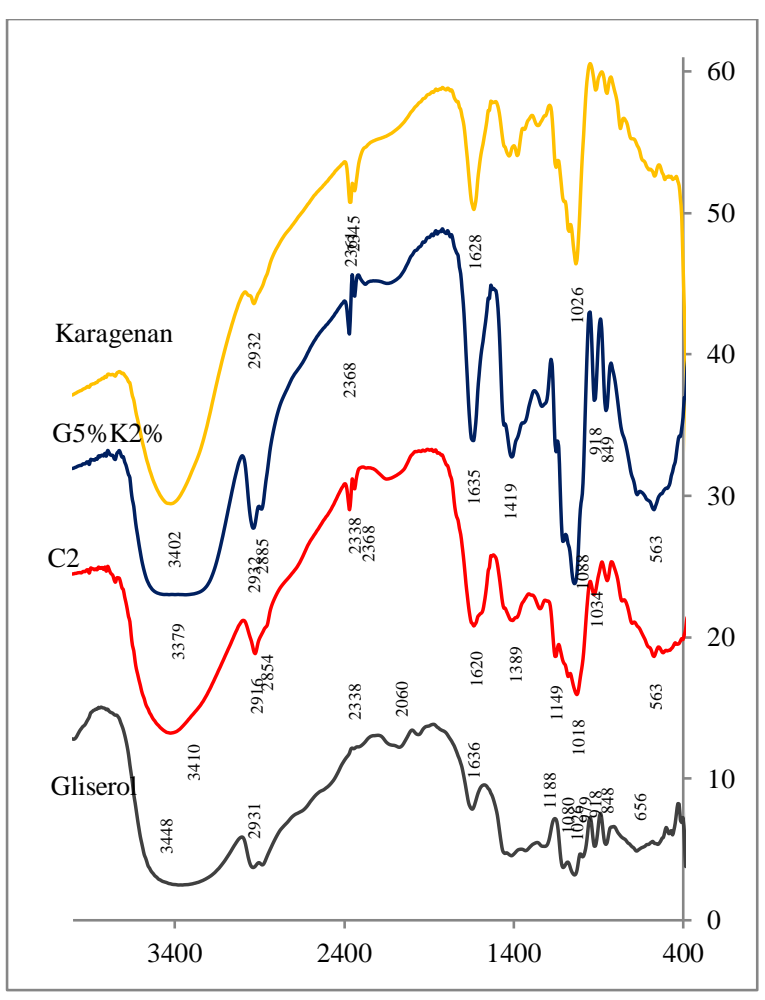

Gambar 7. Spektra IR karagenan, gliserol dan edible film

Vibrasi ikatan $\mathrm{C}-\mathrm{H}$ dalam molekul $\mathrm{CH}_{2}$ alkana tidak begitu terlihat pada spectra IR gliserol. Hal tersebut kemungkinan karena banyaknya oksigen yang bersifat elektronegatif disekitar molekul sehingga dapat membentuk ikatan hidrogen (bersifat elektropositif dengan molekul $\mathrm{CH}_{2}$.

Peak yang kuat pada 1375 - 1325 juga dimili oleh G5\% K2\%, hal ini karena pengaruh vibrasi ikatan $\mathrm{S}-\mathrm{O}$ dan $\mathrm{S}=\mathrm{O}$ (karagean). Gugus fungsi keton/ aldehid dimiliki oleh gliserol, karagenan dan pati. Hal ini terlihat dari munculnya peak pada bilangan gelombang $1660-1600 \mathrm{~cm}^{-1}$. Peak yang paling kuat dimiliki oleh G5\%K2\%. Kuatnya peak tersebut mengindikasikan bahwa vibrasi ikatan $\mathrm{C}=\mathrm{O}$ lebih banyak dan kuat, konsentrasinya pun besar. Sementrasa pada gliserol vibrasinya paling lemah.

Gugus hemiketal/ hemiasetal dapat terjadi oleh reaksi antara keton/aldehid dengan alcohol, sehingga peak pada bilangan gelombang1200-1020 cm-1hanya terdeteksi pada karagenan, C2 dan G5\% $2 \%$. Perbedaan rantai karbon molekul gliserol dengan yang lainnya adalah tidak memiliki rantai siklis, sehingga banyak peak yang muncul di daerah sekitar $720 \mathrm{~cm}^{-1}$. pengaruh gliserol pada G5\% K2\% sangat terlihat, sebab memiliki peak yang kuat dan tajam.

\section{Analisis Mekanik Edible Film}

\section{Uji Kecerahan}

Kualitas edible film salah satunya dapat dilihat dari tingkat kecerahannya. Semakin cerah warnanya semakin baik kwalitasnya. Berdasarkan hasil uji warna (table 7) diketahui bahwa edible film baik termodifikasi maupun tidak termodifikasi (control) berwarna putih kekuningan dan cerah, sebab nilai $\mathrm{Y} 1, \mathrm{~W} 1$ dan $\Delta \mathrm{E}$ menujukkan angka yang positif (+). Edible film yang paling cerah adalah dengan formulasi gliserol 5\% dan karagenan $1 \%$ (G5\%K1\%), dengan index keputihan sebesar 62,303. Gliserol memberikan pengaruh terhadap warna edible film. Penambahan gliserol menjadikan warna edible film semakin gelap, diantara perlakuan gliserol 5\%; $10 \%$ dan 15\%, warna edible film yang paling cerah adalah perlakuan dengan gliserol $5 \%$. Hal ini mengindikasikan bahwa pada konsentrasi karagenan yang sama, semakin pekat konsentrasi gliserol yang ditambahkan, semakin gelap warna film yang dihasilkan.

\section{Tabel 2 Hasil Uji Warna Edible Film}

\begin{tabular}{|l|r|r|r|r|r|r|}
\hline Sampel & $\mathrm{L}$ & $\mathrm{a}$ & $\mathrm{b}$ & $\Delta \mathrm{E}$ & $\begin{array}{r}\text { index } \\
\text { kunin } \\
\mathrm{g}(\mathrm{YI})\end{array}$ & $\begin{array}{r}\text { index } \\
\text { putih } \\
\text { (WI) }\end{array}$ \\
\hline $\begin{array}{l}\text { K1\% } \\
\text { (kontrol }\end{array}$ & 64 & 12 & 9, & 0 & 20,37 & 61,41 \\
) & & 2 & & 7 & 4 \\
\hline $\mathrm{K} 2 \%(\mathrm{k}$ & 59 & 11 & 10 & 0 & 25,82 & 56,30 \\
ontrol) &, 2 &, 4 &, 7 & & 1 & 7 \\
\hline K3\%(k & 65 & 12 & 10 & 0 & 22,60 & 61,65 \\
ontrol) &, 1 & 1 &, 3 & & 3 & 3 \\
\hline G5\%K1 & 65 & 12 & 9, & 1,3 & 20,44 & 62,30 \\
$\%$ &, 7 &, 5 & 4 & 15 & 0 & 3 \\
\hline G10\%K & 42 & 5, & 11 & 22, & 37,47 & 41,35 \\
$1 \%$ &, 7 & 5 &, 2 & 836 & 1 & 7 \\
\hline G15\%K & 39 & 9, & 16 & 26, & 58,97 & 36,24 \\
$1 \%$ & & 2 &, 1 & 565 & 6 & 4 \\
\hline G5\%K2 & 55 & 6, & 10 & 5,8 & 27,65 & 54,00 \\
$\%$ &, 8 & 7 &, 8 & 02 & 0 & 9 \\
\hline G10\%K & 44 & 6, & 14 & 15, & 44,84 & 42,52 \\
$2 \%$ &, 6 & 2 & & 846 & 4 & 3 \\
\hline G15\%K & 39 & 8, & 3, & 20, & 13,60 & 39,22 \\
$2 \%$ &, 9 & 2 & 8 & 745 & 6 & 4 \\
\hline G5\%K3 & 61 & 12 & 10 & 3,2 & 24,69 & 58,55 \\
$\%$ & 99 &, 3 &, 7 & 31 & 5 & 9 \\
\hline G10\%K & 36 & 8 & 11 & 28, & 45,80 & 35,21 \\
$3 \%$ &, 8 & &, 8 & 635 & 8 & 2 \\
\hline G15\%K & 41 & 9, & 3, & 24, & 11,70 & 40,69 \\
$3 \%$ &, 5 & 1 & 4 & 770 & 4 & 9 \\
\hline Ket: & & & & & \\
\hline
\end{tabular}

Ket:

$\Delta \mathrm{E}(+)$ lebih cerah; dan (-) menunjukkan gelap dari standar

YI (+) berwarna lebih kuning; (-) menunjukkan warna lebih biru dari standar 
WI (+) berwarna lebih putih; (-) menunjukkan warna lebih hitam dari standar

\section{Uji Kuat Tarik dan Persen Pemanjangan}

Hasil pengujian kuat tarik pada Gambar 13 menunjukkan gliserol dan karagenan berpengaruh pada kuat tarik edible film. Kuat tarik kontrol K5\%; $\mathrm{K} 10 \%$ dan $\mathrm{K} 15 \%$ (tanpa gliserol) lebih tinggi dari sampel edible film yang mengandung gliserol. Kuat tarik yang rendah pada sampel yang mengandung gliserol, disebabkan oleh sifat hidrofilik gliserol dapat mempercepat penyerapan uap air di udara sehingga film menjadi lebih cepat rusak saat ditarik. Hal serupa juga terjadi pada edible film berbahan dasar tepung jali. Gliserol dapat memperlemah kekuatan pada ikatan polimer (Anandito, Nurhartadi, \& Bukhori, 2012).

Semakin tinggi konsentrasi karagenan, berdampak pada kuat tarik edible film yang semakin besar. Sifat gel karagenan telah menyebabkan matrik penyusun film menjadi semakin kuat. Pada percobaan ini, diperoleh kuat tarik optimum sebesar $12,3 \mathrm{~N}$ pada $\mathrm{K} 15 \%$ (kontrol). Pengaruh karagenan yang juga terliat sama pada sampel edible film G5\%K1\%; G5\%K2\%; G5\%K3\% yakni memiliki pola grafik semakin meningkat. Pada konsentrasi karagenan yang sama, kuat tarik edible film yang optimum ditunjukkan oleh sampel G5\%K3\% $(3,4 \mathrm{~N})$, sementara pada $\mathrm{G} 10 \% \mathrm{~K} 3 \%$ dan $\mathrm{G} 15 \% \mathrm{~K} 3 \%$ memiliki pola grafik menurun yang mengindikasikan bahwa kuat tarik pada edible semakin lemah. Permukaan lapisan edible film yang tidak rata saat pencetakan, film yang tipis, serta suspensi film yang encer juga dapat meyebabkan kuat tarik tidak stabil seperti yang terlihat pada G5\%K1\%; G10\%K1\%; G15\%K1\% dan G5\%K2\%; G10\%K2\%; G15\%K2\%. Semakin banyak penambahan karagenan, film yang dihasilkan semakin tebal. Menurut Dwimayasanti, (2016), penambahan karagenan menyebabkan kuat tarik lapisan film semakin tinggi. Japanese Industrial Standar telah menetapkan standar minimal kuat tarik edible film sebesar 3,92 $\mathrm{MPa}$, jadi semua sampel edible film tidak memenuhinya standar.

Persen pemanjangan (elongasi) edible film berbahan dasar pati dapat meningkat dengan penambahan plasticizer (Ginting, 2012). Hal serupa terlihat pada perbandingan grafik sampel edible film (mengandung gliserol) dan kontrol (tanpa gliserol) dalam gambar 14. Elongasi optimum dalam percobaan ini adalah 43,3\% (G10\%K3\%), sementara pada kontrol optimum pada $16,67 \%$ (K3\%). Gliserol dapat menebabkan sweeling pada film, sehingga ikatan antar molekul jenjadi renggang, gerakan ranai polimen menjadi lebih bebas (semakin elastis) (Nafiyanto, 2019). Pada setiap grafik elongasi, sampel dengan konsentrasi gliseserol $10 \%$ memiliki persen elongasi optimum. Hal tersebut menunjukkan bahwa ikatan hidrogen terbentuk dengan yang kuat antara molekul pati, karagenan dan gliserol dan menjadi jenuh pada konsentarsi gliserol 15\%. Pola grafik yang berlawanan antara grafik kuat tarik dan grafik elongasi, menunjukkan bahwa kandungan gel dalam karagenan dapat menambah ketebalan film dan meningkatkan kuat tarik namun elongasi edible film berkurang. Sebaliknya gliserol sebagai plasticizer dapat meningkatkan persen elongasi namun kuat tarik menjadi lemah. Japanese Industrial Standar memnetapkan bahwa elongasi yang baik berkisar antara $10-50 \%$, dan sangat baik jika melebihi $50 \%$. Oleh sebab itu, semua sampel edible film tergolong memiliki elongasi yang sesuai standar.

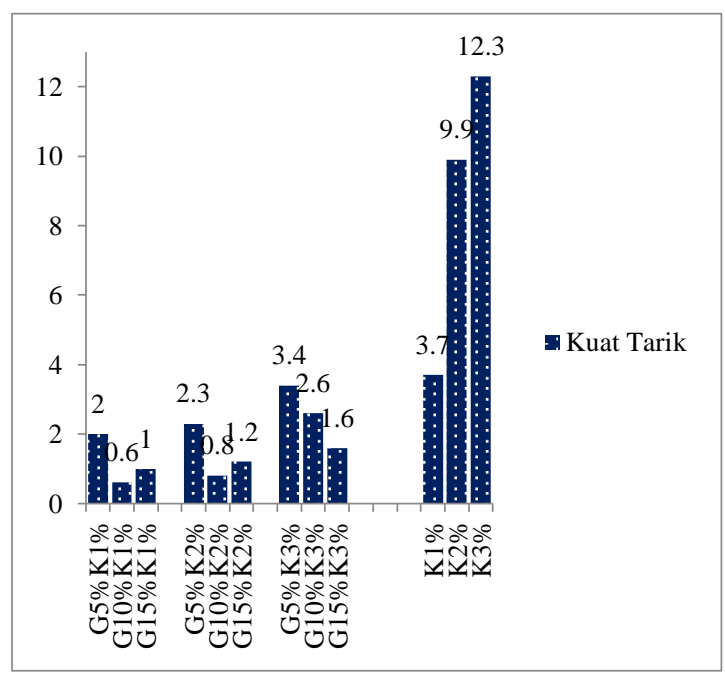

Gambar 8 Hasil Uji Kuat Tarik Edible Film

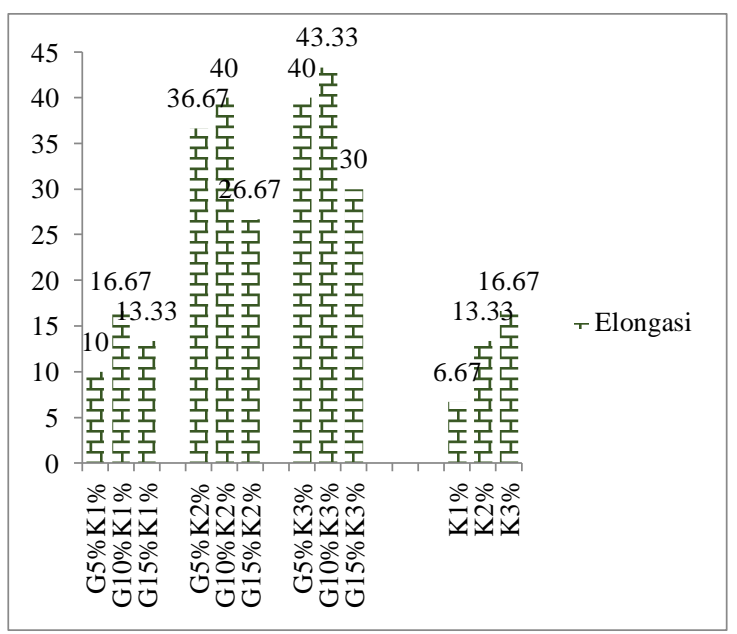




\section{PENUTUP \\ KESIMPULAN}

Karaktistik dan kualitas tepung jagung putih dari Kabupaten Sumbawa dapat diketahui dengan FTIR dan uji proksimat serta uji warna. Spektra IR menunjukkan bahwa tepung jagung Sumbawa tersusun dari gugus fungsi alkana, alkohol, keton/aldehid, hemiaketal dan hemiasetal yang merupakan gugus fungsi dari molekul karbohidrat. Sementara hasil uji proksimat menunjukkan bahwa tepung jagung Sumbawa memiliki kadar air, abu, lemak, protein, karbohidrat, amilosa, amilopektin serta pati berurut - turut: $12,61 \% ; 0,72 \% ; 0,08 \% ; 0,41 \% ; 86,17 \% ; 55,40 \%$; $19,84 \% ; 77,30 \%$. Hasil uji warna tepung jagung menunjukkan bahwa tepung jagung tanpa perlakukan memiliki warna putih tulang dan gelap, sehingga dalam penggunaanya sebagai bahan edile film perlu dimodifikasi dengan cara perendaman dalam natrium metabisulfit kemudian difermentasi untuk mengurangi kadar asam fitat yang bersifat antinutrisi dalam tepung jagung.

Sifat fisik dan mekanik dari edible film berbahan dasar tepung jagung putih diketahui menggunakan uji warna, kuat tarik dan persen pemanjangan film didukung oleh FTIR. Hasil FTIR menunjukkan pengaruh gliserol dan karagenan terlihat dari vibrasi ikatan O-H (3400-3300 $\left.\mathrm{cm}^{-1}\right)$, vibrasi ikatan $\mathrm{CH}_{2}$ (1465 cm-1) overlap dengan vibrasi ikatan $\mathrm{S}-\mathrm{O}, \mathrm{S}=\mathrm{O}$ pada karagenan, vibrasi ikatan $\mathrm{C}-\mathrm{O}, \mathrm{C}=\mathrm{O}\left(1600 \mathrm{~cm}^{-1}, 1200-1020 \mathrm{~cm}^{-1}\right)$ yang terlihat pada spektra IR edible film G5\% K2\%. Konsentrasi optimal gliserol dan karagenan dalam pembuatan edible film tepung jagung putih yakni: gliserol 5-10\% dan karagenan 3\% sebab memiliki elongasi dan kuat tarik optimum serta warna edible film yang cerah. Elongasi dan kuat tarik optimum berturut - turut : $40-43.33 \% ; 2,4-3,6$ N. Hasil uji warna sampel edible film dengan kandungan gliserol 5-10\% dan karagenan 3\% menunjukkan index keputihan 54-58.

\section{UCAPAN TERIMA KASIH}

Penulis mengucapkan terimaksih atas bantuan dari Applied of Chemistry Department, Chaoyang University of Technology, Taiwan, Kemenristek Dikti, LPPM UTS, Laboran lab Pangan Terpadu, teman-teman dosen, dan civitas akademika UTS, khususnya fakultas teknologi pertanian UTS.

\section{REFERENSI}

Aini, N,, Wijonarko, G,, \& Sustriawan, B, (2016), Sifat Fisik, Kimia, dan Fungsional Tepung Jagung Yang Diperoses Melalui Fermentasi, Agritech, 160-169,

Akbar, M, R,, \& Yunianta, (2014), Pengaruh Lama Perendaman Natrium Metabisulfit Dan Fermentasi Ragi Tape Terhadap Sifat Fisik Kimia Tepung Jagung, Jurnal Pangan Dan Agroindustri, 91-102,

Anandito, R. B. K., Nurhartadi, E., \& Bukhori, A. (2012). Pengaruh gliserol terhadap karakteristik edible film berbahan dasar tepung jali (.Teknologi Hasil Pertanian, $V(2), 17-23$.

Andri, Y, (2017), Konsumsi Plastik Nasional Diproyeksi Tumbuh 6\%, Retrieved Agustus 6, 2019, from https://ekonomi,bisnis,com

Angelia, I, O, \& Hasan, A, A, (2018), Pengaruh Lama Perendaman Dan Konsentrasi Natrium Metabisulfit Terhadap Kandungan Vitamin C Dan Tingkat Kecerahan Dalam Pembuatan Tepung Ubi Jalar, Tepung Jagung Dan Tepung Singkong, JTech, 67-71,

Apriwijaya, L, A, (2018), Pengaruh Rasio Tepung Maizena Dan Tepung Karagenan Terhadap Nilai Gizi Dan Sensoris Nugget Itik, Mataram: Universitas Mataram,

Ardiansyah, R, (2011), Pemnafaatan Pati Umbi Garut Untuk Pemuatan Palstik, Depok: Departemen Teknik Kimia, Fakultas Teknik, UI,

Arief, R, W, Irawati, I, \& Yusmasari, (2011), Penurunan kadar Asam Fitat Tepung Jagung Selama Proses Fermentasi Menggunakan Ragi Tape, Seminar NAsional Serelia, 590-597,

Arief, R,, \& Asnawi, R, (2009), Kandungan Gizi dan Komposisi Asam Amino beberapa Varietas Jagung, Jurnal Peneliian Pertanian Terapan,

Azra, M, (2012), Diet Sehat Dengan Makanan Berserat, Solo: Tiga Serangkai Pustaka Mandiri,

Carriedo, M, (1994), Edible Coating And Film Based On Polysacharides In Edible Films To Improve Food Quality, Pennyslvania: Technomic Publishing Company Inc,

Dwimayasanti, R. (2016). Pemanfaatan Karagenan Sebagai Edible Film. Oseana, XII(2), 8-13.

Estiningtyas, H,R, (2010), Aplikasi Edible Film Maizena Dengan Penabahan Ekstrak Jahe Sebagai Antioksidan Alami Coating Sosis Sapi, Surakarta: Fakultas Pertanian, Universitas Sebelas Maret,

Gennadios, (2002), Population Improvment of MAize, Brending Division of CIMMYT, Training Of Specialitys Maize Brending, El Batan Mexico, CYMMYT, 
Geochembio, (2010), Kernel Anatomy, Retrieved from

www,geochembio,com/biology/organisms /maize

Ginting, R. Y. dan E. (2012). Perbedaan Karakteristik Fisik Edible Film dari Umbiumbian yang Dibuat dengan Penambahan Plasticizer. Penelitian Pertanian Tanaman Pangan, (1990), 131-136.

Glicksmen, M, (1998), Food Hydrocolloids, Florida: CSR Press Inc,

Gontard, N,, Guilbert, S,, \& Cuk, J, (1993), Water And Glycerol As Plasticizer Affect Mechanical And Water Vapour Brrier Properties Of An Edible What Gluten Film, J, Food and Science, 206-211,

Handito, D, (2011), Pengaruh Konsentrasi Karagenan Terhadap Sifat Fisik Dan Mekanik Edible Film, Agroteksos, 21-23,

Handito, D, (2011), Pengaruh Konsentrasi Karagenan Terhadap Sifat Fisik Dan Mekanik Edible Film, Agroteksos, 151157 ,

Hui, Y, (2006), "Handbook Of Food Science" Technology And Engginering, USA: Mantano State University,

Huri, dan Fithri, (2014), Keragaman Genetik, Korelasi Antar Sifat dan Pengaruh Seleksi Pada Sutu Sifat Terhadap Kacang Kedalai, Padjajaran: Fakultas Pertanian Universitas Padjajaran,

Iwata, K, Ishaki, S, Handa, A, \& Tanaka, M, (2000), Preparation And Caharacterization Of Edible Film From Fish Water- Soluble Proteins, Fisher Science, 372-378,

Jacob, A, M, Nugraha, R,, \& Utari, S, P, (2014), Pembuatan Edible Film Dari Pati Buah Lindur Dengan Penambhan Gliserol Dan Karagnen, JPHPI, 14-21,

Kester, J, \& Fennema, O, (1986), Edible Films And Coating: A Review, Food Technology, 4749 ,

Kristanoko, H, (2000), Pengaruh Penambahan CMC Dan Sorbitol Terhadap Karakteristik Fisik Edible Film Dari Bungkil Kedelai, Bogor: Fakultas Teknologi Pertanian, IPB,

Krochta, J, (1994), Edible Coating And Films To Improve Food Quality, New York: CRC Press Boca Raton,

Kusumawati, Dyah Hayu; Putri, Widya Dwi Rukmini;, (2013), Karakterisasi Fisik dan Kimia Edible Film Pati Jagung Yang Diinkorporasi Dengan Perasan Temu Hitam, Jurnal Pangan dan Agroindustri, 90-100,

Linsay, R, (1985), Food Additives dalam O,R, Fennama, New York: Food Chemistry, Marcel Dekker Ink,
Lopulalan, C, (2008), Kajian Formulasi Dan Isothermis Sorpsi Air Biskuit Jagung, Bogos: IPB,

Mulyadi, A, F, Pulungan, M, H, \& Qiyyum, N, (2016), Pembuatan Edible Film Maizena Dan Uji Aktifitas Antibakteri (Kajian Konsentrasi Gliserol Dan Ekstrak Daun Beluntas (Pluchea Indica L,)), Jurnal Teknologi Dan Maanjeman Industri, 149158 ,

Nafiyanto, I. (2019). Pembuatan plastik biodegradable dari limbah bonggol pisang kepok dengan plasticizer gliserol dari minyak jelantah dan komposit kitosan dari limbah cangkang bekicot ( achatina fullica). Inegrated Lab Journal, 7(1), 7589.

https://doi.org/10.5281/zenodo.2656812

Pasireron, M, Sirappa, M, \& Dahamarhudin, L, (2013), Kergaman Genetik Jagung Lokal Di Kbupaten Maluku Barat Daya, Prov, MAaluku, Seminar Nasional Serelia, Maros: Badan Penelitian dan Pengembangan Pertanian, Balitsereal,

Pavia, D, L, Lampman, G, M,, \& Kriz, G, S, (2009), Introduction To Spectroscopy, Washington: Brooks or Cole Cenggage Learning,

Rusli, A, Metusalach, Salengke, \& Tahir, M, M, (2017), Karakterisasi Edible Film Karagenan Dengan Pemlstis Gliserol, JPHPI, 219-229,

Sahabrina, A, N, Abduh, S, B, Hintono, A, \& Pratama, Y, (2017), Sifat Fisik Edible Film Yang Terbuat dari Tepung Umbi Garut Dan Minyak Sawit, Jurnal Aplikasi Teknologi Pangan, 138-142,

Saragih, I, Restuhadi, F,, \& Rossi, E, (2016), Kappa Karagenan Sebagan Bahan Dasar Pembuatan Edible Film, Jom Faperta,

Setiani, W, Sudiarti, T,, \& Rahmidar, L, (2013), Preparasi Dan Karakterisasi Edible Film Dari Poliblend Pati Sukun - Kitosan, Valensi, 100-109,

Sinaga, R, F, Ginting, G, M, Ginting, H, S, \& Hasibuan, R, (2014), Pengaruh Penambhan Gliserol Terhadap Sifat Kekuatan Tarik Dan Pemanjangan Saat Putus Bioplastik Dari Pati Umbi Talas, Jurnal Teknik Kimia USU, 19-24,

Siregar, R, F, Santoso, J,, \& Uju, (2016), Karakterisasi Fisiko Kiia Kappa Karagenan hasil Degradasi Menggunakan Hidrogen Peroksida, JPHPI, 256-266,

Sperling, L, (1992), Introdutution Of Physical Polymer Science, 2nd Ed, New York: Jhon Wiley,

Susilawati, B,, Syam, H,, \& Fadhilah, R, (2018), Pengaruh Modifikasi Tepung Jagung Pragelatinasi Terhadap Kualitas Cookies, 
Jurnal Pendidikan Teknologi Pertanian, 27 -48 ,

Voulda, D, (2010), Kajian Senyawa Metabolit Primer Dan Sekunder Dari Rumput LAut, Seminar Nasional Basic II (pp, 169-179), Ambon: Universitas Pattimura,

Watson, S, (2003), Description, Development, Structure And Composition Of The Corn Kornel, Di Dalam White P,J Dan L,A Jonson (eds) Corn, St, Paul, Minnesota, USA: Chemistry And Technology,
Winarno, (2008), Pangan, Gizi, Teknologi Dan Kemasan, Jakarta: Gramedia Pustaka Utama,

Yusuf, A, P,, \& Syamsuddin, (2013), Jagung Makanan Pokok Untuk Mendukung Ketahanan Pangan di Provinsi NTT, Seminar Nasional Serelia, Maros: Pusat Penelitian dan Pengembngan Pertanian (Puslitbantan), Blitsereal, 